\title{
Specyfika i rola rzeczy w codzienności nauczycieli praktycznej nauki zawodu
}

\begin{abstract}
STRESZCZENIE
Celem artykułu jest ukazanie specyfiki i roli rzeczy w codzienności nauczycieli praktycznej nauki zawodu. Analiza wyników badań jakościowych pozwoliła dostrzec duże znaczenie rzeczy w codziennej pracy nauczycieli szkół zawodowych. Nauczyciel pozbawiony dostępu do rzeczy miałby ogromne trudności z przekazaniem swoim uczniom określonych umiejętności praktycznych - są one nieodzownym ogniwem procesu nauczania - uczenia się. Rzeczy mogą stanowić zagrożenie dla życia i zdrowia zarówno nauczycieli, jak i uczniów. Często stają się także dodatkowym bytem, za który nauczyciel ponosi odpowiedzialność w klasie. Odpowiednie wyposażenie szkoły w przedmioty i narzędzia decyduje o jej prestiżu. Rzeczy stanowią element konkurencyjności między szkołami. Niektóre mogą nawet pełnić rolę dyscyplinującą.
\end{abstract}

SŁOWA KLUCzOWE: rzeczy, szkoła zawodowa, codzienność, nauczyciel zawodu

\section{Wprowadzenie}

Okazuje się, że nastały dni, kiedy my - ludzie, musimy pochylić się ku rzeczom. Zwrócić im odbierane przez wiele lat znaczenia. Uczynić je centrum uwagi. Należy wyzbyć się założenia, które głosi, że rzeczy konkurują z człowiekiem o miano niezawodnych, efektywniejszych, bo np. kalkulator wykonuje obliczenia natychmiastowo, a człowiek musi się nad tym skupić, poświęcić więcej czasu i istnieje duże prawdopodobieństwo, że wynik okaże się błędny. Uznając wspomniane urządzenie za pożyteczne czy wręcz niezbędne, nie stajemy się jego konkurentem. Świat ludzi i rzeczy nigdy nie był, nie jest i z całą pewnością nie będzie nastawiony względem siebie antagonistyczne. To rzeczy, te z pozoru prymitywne, pozwoliły stać się nam ludźmi w takim wymiarze funkcjonowania, jakiego obecnie doświadczamy. Wyprostowana postawa, przeciwstawny kciuk, znakomicie rozwinięta zdolność komunikowania się z przedstawicielami tego samego gatunku - na te cechy i umiejętności błędnie wskazujemy, gdy chcemy określić, gdzie tkwi wyjątkowość gatunku ludzkiego. Mam świadomość, że jest to powierzchowna ocena, gdyż „istota człowieczeństwa polega na nieustannym wkraczaniu dzięki technologicznym ekstensjom poza możliwości i ograni- 
czenia, które stwarza nasza biologiczna konstytucja” (Krajewski, 2008, s. 44). Wbrew pozorom, to właśnie te błahe rzeczy, jakimi się otaczamy i posługujemy, definiują nas. Przedmioty nas osaczają; są przed nami, pod nami, na nas. Mają moc sprawczą, można je zatem analizować w „kategoriach aktywnego aktora” (Rybus, 2015, s. 19). Są „pełnoprawnym uczestnikiem tworzenia rzeczywistości” (Domańska, 2008, s. 14). W ciągu całego życia, niemal podczas każdej wykonywanej przez nas czynności wykorzystujemy przedmioty. Stanowią one zatem istotny element naszej codzienności.

Właśnie na pojęcie codzienności chciałam zwrócić uwagę w niniejszym tekście. Doświadczają jej bez wątpienia wszyscy ludzie - bez względu na wiek, rasę, status materialny, czy wykonywany zawód. Nie da się więc ukryć, że „podstawę naszego istnienia stanowi codzienność” (Brach-Czaina, 1995, s. 55). Jest ona opisywana jako „każdy powtarzalny, cykliczny rytmiczny i rutynowy cykl zdarzeń, realizujący się nierzadko w postaci zrutynizowanej, nawykowej, wykonywanej według określonego scenariusza" (Kopciewicz, 2009, s. 108). Żeby wspomniany scenariusz mógł zostać zrealizowany, a role właściwie odegrane, potrzebne są zazwyczaj odpowiednie rekwizyty - urządzenia, narzędzia, przedmioty. Jednym słowem rzeczy.

W tym artykule stawiam pytanie, jakie znaczenie mają rzeczy w codzienności nauczycieli praktycznej nauki zawodu. Szkoły zawodowe w ostatnich latach stanowiły temat rozmów i analiz pracowników oświatowych. W rezultacie, zgodnie z ustawą - Prawo oświatowe z 14 grudnia 2016 roku (Dz.U. z 2017 r. poz. 59), od 1 września 2017 roku szkoły zawodowe przekształciły się w trzyletnie branżowe szkoły I stopnia. Nie podlega jednak wątpliwości, że zarówno w jednym i w drugim typie szkoły nadrzędnym celem jest kształtowanie u uczniów umiejętności koniecznych do wykonywania określonego zawodu. Uzasadniony jest zatem duży nacisk kładziony na zajęcia praktyczne, czego potwierdzeniem może być ich duża liczba w tygodniowym planie zajęć. W trakcie zajęć praktycznych niezbędne jest posługiwanie się określonymi, wspominanymi już wielokrotnie, przedmiotami. Wydaje się niemożliwe nauczenie prawidłowej techniki ścięcia pasma włosów za pomocą jedynie słów czy rycin poglądowych, bez wykorzystania prawdziwych nożyczek. Podobnie jest z kwestią wymiany silnika w samochodzie - trudno nauczyć tak skomplikowanych czynności bez przećwiczenia tego na prawdziwych egzemplarzach. Celem artykułu jest rozpoznanie specyfiki i roli rzeczy w codzienności nauczycieli praktycznej nauki zawodu. W tekście zaprezentuję wyniki prowadzonych przeze mnie badań ${ }^{1}$.

1 Badania prowadzone były w ramach seminarium licencjackiego, prowadzonego przez dr hab. Alicję Korzeniecką-Bondar w roku akademickim 2017/2018. 
Tekst składa się z trzech części. W pierwszej starałam się przyjrzeć kategorii rzeczy, w drugiej opisałam założenia metodologiczne badań własnych, a w ostatniej zaprezentowałam analizę wyników badań.

\section{Rzeczy nastał czas}

Jednym z godnych uwagi fenomenów ludzkiego istnienia są relacje człowieka i rzeczy. Do lat 80. XX wieku temat ten rzadko czyniono obiektem pogłębionych refleksji. Celnego spostrzeżenia dokonali Maksymilian Chutorański i Aneta Makowska:

Rzeczy nie należą do przedmiotów badań cieszących się szczególną estymą wśród (większości) pedagogów. Widzimy ważniejsze problemy: neoliberalizm, ideologie, poczucie podmiotowości, świadomość, wartości, narracje nauczycieli, znaczenia, kompetencje, instytucje, politykę. Materialności, jeśli stają się dostrzegalne, to najczęściej jako mgliste tło ludzkich działań, kontekst, coś, co jest istotne ze względu na coś innego: niematerialne aspekty kultury, postawy, uczniowskie reprezentacje etc. Tymczasem edukacja tkana jest zarówno $\mathrm{z}$ wartości, ideologii, dyskursów, relacji międzyludzkich, jak i przez szereg różnych relacji, które tworzymy z rzeczami, zwierzętami, roślinami, bakteriami etc. (2019, s. 9).

Autorzy obnażają w pewnym stopniu naszą słabość do przypisywania ludziom i ich zachowaniom hegemonii w kreowaniu świata. Sytuacja stopniowo ulega zmianie. Radosław Sierocki, polski socjolog i etnolog, zauważa, że zdajemy sobie sprawę z tego, że

nie potrafimy żyć bez rzeczy nie tylko dlatego, że musimy umyć rano zęby szczoteczką do zębów, zjeść śniadanie z talerza, wypijając przy tym poranną kawę z filiżanki, siedząc na krześle przy drewnianym stole, a dlatego, że powierzamy rzeczom naszą tożsamość, utrwalamy w rzeczach i poprzez rzeczy nasze społeczeństwo oraz zapisujemy zasady i wartości leżące u podstaw naszej kultury, zwierzamy rzeczom losy naszej codzienności (nie zawsze je rozumiejąc) w taki sposób, że ewentualne zniknięcie klas czy typów rzeczy nie może nie pozostać bez wpływu na trwanie i kształt społeczeństwa oraz kultury (2008, s. 175).

Badacz pisze o powracaniu do „zapomnianych i zakurzonych bohaterów, jakimi są rzeczy, przedmioty, artefakty" (s. 175). Ewa Domańska zaś dostrzega potrzebę „zwrotu ku rzeczom”, „zwrotu ku temu-co-nie-ludzkie” (2007, s. 52). Jak zauważył socjolog Marek Krajewski, mimo że zagadnienie związków ludzi i przedmiotów było podejmowane, koncentrowano się zazwyczaj na niebezpieczeństwach, jakie rzeczy niosą człowieczeństwu (2008, s. 44). Moją intencją jest przyjrzenie się rzeczom w codzienności szkolnej nauczycieli praktycznej nauki zawodu. 
Prologiem moich rozważań chciałabym jednak uczynić eksplikację samego pojęcia rzeczy. Nie jest to jednak sprawa prosta. Najtrudniej bowiem definiuje się te z pozoru oczywiste pojęcia. Cytując definicję zawartą w słowniku języka polskiego, rzecz to „cokolwiek, co może być przedmiotem postrzeżenia zmysłowego, ma właściwości przestrzenne, trwa w czasie i czemu przypisujemy byt od nas niezależny”. O ile pierwsza część definicji nie jest „poznawczą awangardą”, o tyle zwrot "byt od nas niezależny” w niniejszej pracy nie może zostać zignorowany. Oczywiście może zdarzyć się, że to ludzie, wytwarzając kolejne przedmioty, użytkując je, stają się powoli ich niewolnikami. Są to jednak sytuacje patologiczne.

Przedmioty, które początkowo wydawały się dla ludzi szaleństwem, stają się po jakimś czasie przedmiotami, bez których trudno wyobrazić sobie życie. Przykładem może być powstanie radioodbiorników i możliwość nagrywania dzięki nim głosu. Początkowo było to, m.in. dla Józefa Piłsudskiego, wariactwo. Znane jest jego przemówienie $\mathrm{z} 1924$ roku, podczas którego powiedział: „Stoję przed jakąś dziwaczną trąbą i myślę, że głos mój ma się oddzielić ode mnie i pójść gdzieś w świat beze mnie (...). Zabawne pomysły mają ludzie" (Kanał Polskie Radio, YouTube). Jak się okazuje, po pewnym czasie te zabawne rozwiązania stają się koniecznością, a pula przedmiotów, bez których nie wyobrażamy sobie życia ciągle się powiększa.

\section{Metodologia badań własnych}

Celem przeprowadzonych badań był opis, analiza i interpretacja codzienności szkolnej nauczycieli zawodu. Analiza materiału empirycznego ukazała dużą obecność i znaczenie codziennych przedmiotów, stąd też na tym wątku postanowiłam się skupić. Na potrzeby artykułu raz jeszcze poddałam analizie zgromadzony materiał empiryczny starając się znaleźć odpowiedź na dwa pytania badawcze:

1) jakie cechy mają rzeczy wykorzystywane w codzienności szkolnej nauczycieli praktycznej nauki zawodu?

2) jaką rolę pełnią rzeczy w codzienności szkolnej nauczycieli praktycznej nauki zawodu?

Materiał empiryczny zgromadziłam dzięki zastosowaniu metody indywidualnych przypadków, wykorzystując indywidualny, częściowo ustrukturyzowany wywiad.

Badania zostały przeprowadzone w lutym 2018 roku. Głównym kryterium celowego doboru próby był fakt prowadzenia przez nauczyciela praktycznej nauki zawodu. Realizując badania rozmawiałam z pięcioma osobami - dwiema kobietami i trzema mężczyznami. Były to osoby w wieku 39-55 lat. 
Ich staż pracy wahał się od 8 do 35 lat. Profile uczestników przedstawiam w tabeli 1.

Tabela 1. Profile badanych nauczycieli

\begin{tabular}{|c|c|c|c|l|l|l|}
\hline KOD & PŁEĆ & WIEK & $\begin{array}{c}\text { STAŻ } \\
\text { PRACY }\end{array}$ & $\begin{array}{c}\text { WYY- } \\
\text { KSZTAECE- } \\
\text { NIE }\end{array}$ & $\begin{array}{c}\text { STOPIEN } \\
\text { AWANSU } \\
\text { ZAWODO- } \\
\text { WEGO }\end{array}$ & \multicolumn{1}{|c|}{$\begin{array}{l}\text { NAUCZANY } \\
\text { PRZEDMIOT }\end{array}$} \\
\hline K.1 & Kobieta & 39 & 10 & $\begin{array}{l}\text { wyższe } \\
\text { magisterskie }\end{array}$ & $\begin{array}{l}\text { nauczyciel } \\
\text { dyplomo- } \\
\text { wany }\end{array}$ & $\begin{array}{l}\text { praktyczna nauka } \\
\text { zawodu - fryzjer- } \\
\text { stwo }\end{array}$ \\
\hline K.2 & Kobieta & 48 & 8 & $\begin{array}{l}\text { wyższe } \\
\text { licencjackie }\end{array}$ & $\begin{array}{l}\text { nauczyciel } \\
\text { mianowany }\end{array}$ & $\begin{array}{l}\text { praktyczna nauka } \\
\text { zawodu - fryzjer- } \\
\text { stwo }\end{array}$ \\
\hline M.1 & mężczyzna & 40 & 11 & $\begin{array}{l}\text { wyższe } \\
\text { magisterskie }\end{array}$ & $\begin{array}{l}\text { nauczyciel } \\
\text { dyplomo- } \\
\text { wany }\end{array}$ & $\begin{array}{l}\text { praktyczna nauka } \\
\text { zawodu - mecha- } \\
\text { nika pojazdów } \\
\text { samochodowych }\end{array}$ \\
\hline mężczyzna & 41 & 9 & $\begin{array}{l}\text { wyższe } \\
\text { magisterskie }\end{array}$ & $\begin{array}{l}\text { nauczyciel } \\
\text { mianowany } \\
\text { zawodu, budowni- } \\
\text { ctwo - technologia } \\
\text { drewna }\end{array}$ \\
\hline mężczyzna & 55 & 35 & $\begin{array}{l}\text { wyższe } \\
\text { magisterskie }\end{array}$ & $\begin{array}{l}\text { nauczyciel } \\
\text { dyplomo- } \\
\text { wany }\end{array}$ & $\begin{array}{l}\text { praktyczna } \\
\text { i teoretyczna nauka } \\
\text { zawodu - budow- } \\
\text { nictwo }\end{array}$ \\
\hline
\end{tabular}

Źródło: wyniki badań własnych.

Prowadząc badania, szczególną uwagę zwracałam na kwestie etyczne, gdyż „przeprowadzenie wywiadu jest przedsięwzięciem moralnym” (Kvale, 2004, s. 116). Dlatego też, podczas przygotowywania i przeprowadzania badań oraz analizy zgromadzonego materiału empirycznego miałam na uwadze następujące kwestie etyczne: świadomą zgodę badanych, poufność oraz skutki uczestnictwa w badaniach (Kvale, 2004, s. 119-123). Przed przystąpieniem do rozmowy każdorazowo przedstawiłam moim rozmówcom pisemny formularz zgody uczestnictwa w badaniu, który zawierał informacje dotyczące m.in. celu badań, wykazu osób, które będą miały dostęp do zgromadzonego materiału. Kolejną kwestią była poufność. Zapewniłam badanych, iż dane tożsamości, które mogłyby pozwolić na ich identyfikację nie zostaną ujawnione. Ostatnią kwestią, jaką miałam na uwadze, były skutki uczestnictwa w badaniach. By badanie nie wywołało negatywnych skutków, starałam się nie zadawać pytań zbyt osobistych, intymnych. Parafrazując słowa przytaczanego już Steinara Kvale, prowadzący wywiad musi mieć na względzie, iż badani mogą żałować przekazania badaczowi, często pod wpływem emocji, 
niektórych informacji (2004, s. 123). Nie spotkałam się z taką sytuacją, gdyż nikt $\mathrm{z}$ badanych nie chciał nawet zapoznać się z transkrypcją wywiadu.

Mam świadomość, że zbadanie doświadczeń tak niewielkiej liczby osób nie uprawnia do uogólnień, ale stwarza możliwość rozpoznania unikatowej sytuacji konkretnych nauczycieli, w konkretnym czasie i miejscu (Glinka, Hensel, 2012).

Analizie poddałam transkrypcje wywiadów, które przeprowadziłam osobiście. Dokonałam kodowania, kolejnym fragmentom tekstu przypisywałam kilka słów podstawowych, co pozwalało na późniejszą identyfikację danej wypowiedzi (Kvale, 2010, s. 172). W dalszej kolejności stworzyłam tabelę, w której wyodrębniłam dwie kategorie: cechy rzeczy oraz ich rolę w pracy nauczycieli praktycznej nauki zawodu. $\mathrm{Z}$ wypowiedzi badanych wyłaniałam kluczowe wątki związane z tymi kategoriami. Dzięki temu mogłam porównać poszczególne wypowiedzi w wymiarach wertykalnym i horyzontalnym, a także wyodrębnić w nich podobieństwa i różnice (Gibbs, 2011). Wypowiedzi badanych poddałam przeredagowaniu, aby złagodzić ich potoczny styl oraz wyeliminować zacięcia głosu rozmówców. Robiłam to z troską, by nie zniekształcić intencji ich wypowiedzi.

\section{Specyfika i rola rzeczy w codzienności szkolnej nauczycieli zawodu - wyniki badań}

Analiza zgromadzonego materiału empirycznego pozwoliła wyłonić kilka cech rzeczy wykorzystywanych przez nauczycieli w szkole. Jedną z nich jest to, że część rzeczy używanych przez nauczycieli stanowi zagrożenie dla zdrowia i życia. Szczególną uwagę zwróciła na ten fakt nauczycielka fryzjerstwa: „cały czas mamy do czynienia $\mathrm{z}$ chemią z rożnymi substancjami szkodliwymi dla zdrowia, z pyłami, z gazami, lakierami do włosów" [K.2.]. Inną egzemplifikacją jest spostrzeżenie nauczyciela sugerującego, że maszyny i narzędzia, którymi operują uczniowie podczas zajęć praktycznych, stanowią realne zagrożenie dla życia nieroztropnych uczniów. Nasuwa się więc pewien wniosek: obecność specyficznego wyposażenia klasopracowni, innego niż standardowa tablica i kreda, przyczynia się do tego, że nauczyciele i uczniowie muszą zwracać szczególną uwagę na zagadnienia związane z zachowaniem bezpieczeństwa i higieny pracy, a tym samym ich uwaga jest wielowymiarowo zagospodarowywana. Pojawia się zatem pierwszy z wielu paradoksów dotyczących rzeczy - z jednej strony optymalizują pracę, z drugiej zaś nakładają na nauczycieli oraz ich uczniów dodatkową odpowiedzialność.

Wobec powyższego warto wspomnieć o instrukcji, z którą należy się $\mathrm{w}$ szkole zapoznać, aby w pełni korzystać z rzeczy. Tak jest również w przy- 
padku praktycznej nauki zawodu. Badani opisywali, że każde zajęcia rozpoczynają od przedstawienia uczniom instruktażu stanowiskowego. Nauczyciele wcześniej, przed bezpośrednią pracą z uczniami, muszą - samodzielnie lub za pomocą szkoleń - posiąść wiedzę na temat wykorzystywanych przedmiotów. To sugeruje, że gros rzeczy stałoby się bezużytecznych, gdyby ludzie nie wkładali trudu $\mathrm{w}$ zapoznanie się $\mathrm{z}$ nimi, $\mathrm{z}$ ich możliwościami, funkcjami. Jeśli chcemy czerpać z przedmiotów, musimy sami coś im dać - siebie, własny intelekt, umiejętności. Konieczność opanowywania nowych technologii może stanowić dla nauczycieli motywację do rozwoju wówczas, gdy nie odczuwają oni wewnętrznej potrzeby doskonalenia.

Jeden z badanych zwrócił uwagę na istotną cechę rzeczy - przemijalność ich użyteczności. Szczególnie ważne jest to w sytuacji, gdy duża część procesu dydaktycznego bazuje na ich codziennym wykorzystywaniu. Oddam głos wspomnianemu nauczycielowi: „W szkołach zawodowych trzeba śledzić nowinki technologiczne, zwłaszcza w branży motoryzacyjnej. To naprawdę idzie w tak szybkim tempie... Przykładowo, jak ja byłem wykształcony na tamten sam czas [czas studiów - przyp. J.B.-S.] to tyle nowości weszło, między innymi coraz powszechniejsze stały się auta elektryczne, hybrydowe, auta autonomiczne. Także to, co kiedyś było jeszcze przyszłością, hohoho kiedyś tam będzie, to $\mathrm{w}$ tej chwili to już jest. Wszystko naprawdę się zmienia i trzeba iść w tym kierunku (...) trzeba niestety iść za nowinkami” [M.1]. $\mathrm{W}$ tej wypowiedzi można odnaleźć kolejną cechę rzeczy. Przedmioty, jak wynika z ich ogólnej definicji, istnieją materialnie w określonej formie. Trwa to dopóki nie ulegną one intencjonalnemu lub niezamierzonemu rozpadowi. Jednak w rzeczywistości, po upływie określonego czasu, wbrew temu, że wspomniane przedmioty nadal istnieją i mamy je w zasięgu ręki, przestają być nam potrzebne. Niby są, ale na co dzień zupełnie nie zwracamy na nie swojej uwagi. Wystarczy rozejrzeć się dookoła, żeby dostrzec mnóstwo takich rzeczy, które już od wielu lat nie spełniają zaplanowanej im początkowo funkcji. Mijamy je bezrefleksyjnie, a mimo to wciąż są obok nas.

Badani proszeni o opisanie warunków pracy, zawsze na początku odwoływali się do wyposażenia swoich klasopracowni, mimo że pytanie było tak skonstruowane, że mogli wskazać na wiele innych aspektów - liczbę uczniów w klasach, klimat pracy, relacje z dyrektorami i innymi nauczycielami, zarobki, godziny pracy itp. Mimo to, każdy badany zwrócił uwagę na wyposażenie klas, czego egzemplifikacją mogą być następujące wypowiedzi: „mamy stosunkowo dobrze wyposażoną pracownię, mamy odpowiednie materiały, narzędzia, odpowiednie stanowiska egzaminacyjne (...) więc tu nie ma problemu” [M.2], „mamy bardzo dużą pracownię, mamy siedem 
stanowisk fryzjerskich, bardzo fajnie jest pracownia wyposażona, mamy bardzo dużo nowych urządzeń, z których uczniowie korzystają typu: sauna, klimazony, infrazony ${ }^{2}$, mamy różne kosmetyki, także pracownie są naprawdę $\mathrm{w}$ miarę potrzeb wyposażone dobrze" [K.1]. Wyposażenie klas stanowi ważny aspekt pracy nauczycieli szkół zawodowych. Ponadto zasoby materialne szkoły są istotnym czynnikiem budowania wizerunku i prestiżu szkoły. Potwierdzeniem może być wypowiedź jednego z badanych: „mamy wyposażenie na miarę szkoły takiej już naprawdę dobrej” [M.1]. Analizując tę krótką wypowiedź, nasuwa się wiele pytań. Jaka jest szkoła „naprawdę dobra”? Czy oznaką tejże jest odpowiednie zaopatrzenie w narzędzia i urządzenia? Czy wobec tego można wysunąć wniosek, iż braki materialne przesądzają o jakości szkoły? Czy rzeczy usunęły na dalszy plan rolę dobrych nauczycieli, pedagogów, wysokich wyników w egzaminach zewnętrznych? Cytowany wcześniej Marek Krajewski zauważył, że przedmioty stanowić mogą pewnego rodzaju kryteria oceny:

Używane przez nas przedmioty: komputery, zrobotyzowany sprzęt AGD i RTV, samochody, ubrania wykonywane są za pomocą „kosmicznych” technologii - nie tylko zawstydzają nas swoją doskonałością i tym, że nie rozumiemy zasad ich działania, ale również określają kryteria, za pomocą których oceniamy siebie i innych. Do najważniejszych z nich należą: szybkość, niezawodność, wszechstronność, niezniszczalność, perfekcja wykonania (2013, s. 39).

Kwestia subiektywnie przypisywanych atrybutów szkole jako dobrej lub złej stanowi ciekawe pole badawcze warte eksploracji.

Rozmówcy, oprócz przyznania rzeczom roli wzmocnienia prestiżu szkoły, wskazali również, że są one ważnym element konkurowania szkół między sobą. Wyposażenie innych szkół w nowoczesne rzeczy nierzadko stanowi pewnego rodzaju impuls do zmian, wprowadzania udoskonaleń. Dzięki temu przyszli uczniowie mogą korzystać z innowacji i jak najlepiej przygotowywać się do życia i pracy w naszym społeczeństwie. Dobrze wyposażone szkoły mogą stać się tzw. bazą ośrodków egzaminacyjnych, co niesie ze sobą kolejne możliwości. Badani opisywali to następująco: „wyposażenie zmienia się, ponieważ to jest centrum kształcenia praktycznego, tutaj stworzono bazy ośrodków egzaminacyjnych, odbywają się tutaj egzaminy potwierdzające kwalifikacje w zawodzie (...) taki ośrodek egzaminacyjny to dla naszych uczniów wspaniała rzecz. Nie muszą jeździć gdzieś tam po kraju... Z naszych

2 Jest to wielofunkcyjne urządzenie, dzięki któremu wykonuje się takie zabiegi, jak: trwała ondulacja, keratynowe prostowanie, farbowanie, dekoloryzacja, czy po prostu suszenie włosów. 
ośrodków korzystają też inne szkoły z okolicy. Maszyny to droga rzecz. Żeby kupić jakąś maszynę to trzeba mieć sporo pieniędzy" [M.3]. Rozmówca wskazywał, że nie każdy uczeń ma szansę pracować na co dzień przy urządzeniach, przy których następnie zdaje egzaminy. Jest to z całą pewnością swego rodzaju „karta przetargowa”, którą mogą chlubić się szkoły podczas promocji, dni otwartych, mających na celu zachęcenie jak największej liczby uczniów do wyboru właśnie tej placówki.

Rzeczy w znacznym stopniu ułatwiają nasze ludzkie funkcjonowanie. Powszechnie też wiadomo, że odgrywają one ważną rolę w procesie nauczania. Wówczas przyjmują inne nazwy - dydaktycy zwykli określać je środkami dydaktycznymi (Półturzycki, 1999; Okoń, 2016), materiałem rozwojowym (Montessori, 2005), czy pomocami rozwojowymi (Miksza, 2010). W codziennej pracy nauczycieli zawodu rzeczy są konieczne do stworzenia uczniom warunków do nabywania kwalifikacji, stanowią podstawę ich działań. Egzemplifikacją tego może być wypowiedź: „Da się robotę przy samochodzie czy przy jakimś modelu to te 6 godzin jest co zrobić” [M.1]. „Cała nauka oparta jest na bazie ćwiczeń, czyli ćwiczą na materiale zakupionym wspólnie z dyrektorem szkoły" [M.3]. Należy wziąć jednak pod uwagę fakt, że w takim przypadku aktywność nauczyciela jest zdominowana przez rzecz, bowiem nie można oddzielić działań nauczyciela od działań jego uczniów i rzeczy. Nauczyciel działa na rzeczach, pokazuje na nich i stopniowo włącza uczniów w coraz bardziej świadome i odpowiedzialne wykorzystywanie rzeczy w realizacji określonych zadań. Definicja zajęć praktycznych wskazuje, iż nie da się ich przeprowadzić teoretycznie, za pomocą jedynie słowa pisanego lub mówionego. W szkole zawodowej działanie jest kluczowe. Dlatego też rzeczy są w takich sytuacjach niezastąpione. Nawet najlepiej dobrana instrukcja słowna, opis, wskazówki nauczyciela nie zastąpią samodzielnego wykonywania przez uczniów określonych czynności. Przykładem są zajęcia z fryzjerstwa: „ostatnio robiliśmy strzyżenie włosów (...) taki zabieg polega na tym, że najpierw pokazuję uczniom na główce treningowej jak to ma wyglądać, jak mają robić no i później oni robią na swoich główkach” [K.1]. Trzeba podkreślić, że mimo iż to konkretne przedmioty, urządzenia odgrywają tutaj kluczową rolę, to nie można unieważniać roli nauczyciela. Dalej, ta sama nauczycielka kontynuuje: „Ja sprawdzam i kontroluję wszystkie czynności, to co oni wykonują" [K.1]. Rzeczy nie byłyby tak istotne w procesie edukacji, gdyby nie nauczyciel, który odgrywa rolę pewnego rodzaju strażnika dozorującego odpowiednie wykorzystanie przedmiotów. Wobec tego można zauważyć ciekawy łańcuch zależności: zajęcia praktyczne nie miałyby racji bytu bez wykorzystania przedmiotów, a jedynie z obecnością nauczyciela i odwrotnie 
- z wykorzystaniem przedmiotów, ale bez obecności nauczyciela, który koryguje pracę uczniów.

Analiza materiału empirycznego ukazała, że nauczyciele dostrzegają zagrożenie $\mathrm{w}$ rzeczy. Mowa o urządzeniu powszechnym oraz wydaje się, koniecznym dla normalnego funkcjonowania w XXI wieku - telefonie $\mathrm{z}$ dostępem do Internetu. Młodzież określiłaby to jako absolutne must have. Nie chodzi tu jednak o szkodliwość wynikającą z samego typowego korzystania $\mathrm{z}$ telefonu, a raczej $\mathrm{z}$ tego, kto jest jego posiadaczem. Telefon $\mathrm{w}$ rękach ucznia staje się zagrożeniem dla nauczyciela: „W bezstresowym wychowaniu jest gorsza i to o wiele gorsza [młodzież - podkreśl. J.B.-S.], ponieważ ja już mam taki staż pracy [35 lat - podkreśl. J.B.-S.], to musiałem się jakoś przystosować. Musiałem zmienić metody, podejścia do ucznia, bo tam to można było nakrzyczeć na niego i tak dalej, a tutaj niestety trzeba ostrożnie, bo to wiadomo zaraz nagrają. Puszczą gdzieś tam w plener to wszystko. Tacy są uczniowie" [M.3]. Ten fragment wskazuje, jak rzecz może zmienić postawy nauczyciela w stosunku do uczniów. Osoba z długim stażem pracy, bez wątpienia doświadczona, zmienia swoje metody pracy z uczniami pod wpływem jednej rzeczy, która, jak się okazuje, dyscyplinuje w pewien sposób nauczyciela, modyfikuje jego styl komunikacji z uczniami. Lęk, jak pokazuje przytoczony fragment, nie dotyczy samej kwestii nagrania, ale możliwości rozpowszechnienia tego wśród większego grona ludzi. Wypowiedź ta odsłania, że nauczyciel jest świadomy tego, iż niektóre stosowane przez niego formy komunikacji z uczniami nie są aprobowane. Nasuwa się zatem pytanie, czy dopiero pojawienie się nowoczesnych technologii stało się motywem do zmiany stosunku nauczyciela do uczniów. Ujawnia się tu kolejny paradoks - to te same rzeczy, które humaniści postrzegali jako zagrożenie dla człowieka, egzekwują na tym samym człowieku prezentowanie postaw nastawionych na lepszą komunikację z innymi. Jako podsumowanie tej części zacytuję słowa użyte przez Chutorańskiego w nieco innym kontekście, ale pasujące do omawianego wątku „[n]ie zabierajcie nam rzeczy, bo bez nich przestaniemy być ludzcy!” (2016). Wydaje mi się, że wszechobecne kamery, aparaty, sprawiają, że ludzie zwracają większą uwagę na swoje działania, przywiązują uwagę do przepisów, obowiązującego prawa. Robią to jednak nie z uwagi na troskę o jakość relacji międzyludzkich, ale ze strachu przed możliwymi konsekwencjami.

\section{Podsumowanie}

Analiza wypowiedzi nauczycieli wykazała wieloraką rolę rzeczy w codziennej pracy nauczycieli zawodu. Rzeczy mogą stanowić zagrożenie dla życia i zdrowia zarówno nauczycieli, jak i uczniów. Korzystanie z rzeczy i uczenie tego 
innych wymaga instrukcji - wiedzy, jak korzystać bezpiecznie i skutecznie. Rzeczy w szkole stają się także dodatkowym bytem, za który nauczyciel ponosi odpowiedzialność w klasie. Jak odsłoniła analiza materiału, odpowiednie zaopatrzenie w przedmioty i narzędzia decydować może o prestiżu szkoły. Potencjalni kandydaci uznają jedną szkołę „za lepszą” od innych, właśnie ze względu na wyposażenie w przedmioty i narzędzia. Rzeczy stanowią element konkurencyjności między szkołami. Nauczyciel pozbawiony dostępu do narzędzi, przedmiotów, rzeczy miałby trudności z przekazaniem uczniom określonych umiejętności praktycznych - są one nieodzownym elementem procesu nauczania - uczenia się. Zdarza się, że rzeczy pełnią także rolę dyscyplinującą w relacjach nauczyciel - uczeń.

Mam świadomość, że niniejszy artykuł nie wyczerpuje tematyki rzeczy w codzienności szkolnej nauczycieli szkół zawodowych. Traktować go należy jako przyczynek w dyskusji o rzeczach w szkole. Powyższa analiza sygnalizuje jednak, jak ważną i otwierającą przestrzeń do dalszych eksploracji jest problematyka rzeczy w edukacji i w pedagogice.

\section{BIBLIOGR AFIA}

Brach-Czaina, J. (1995). Szczeliny istnienia. Kraków: Wydawnictwo eFKa, Kraków.

Chutorański, M. (2016). Nie(tylko)ludzka pedagogika? [W:] K. Węc, A. Wierciński (red.), Ryzyko jako warunek rozwoju. Transformatywne aspekty edukacji. Toruń: Wydawnictwo Adam Marszałek.

Chutorański, M., Makowska, A. (2019). Czy(m) jest pedagogika rzeczy? Wprowadzenie. W: M. Chutorański, A. Makowska (red.), Rzeczy - Kultura - Edukacja. Szczecin: Wydawnictwo Naukowe Uniwersytetu Szczecińskiego.

Domańska, E. (2007). „Zwrot perfomatywny” we współczesnej humanistyce. Teksty Drugie, 5, 48-61.

Domańska, E. (2008). Humanistyka nie-antropocentryczna a studia nad rzeczami. Kultura Współczesna, 3 (57), 9-21.

Gibbs, G. (2011). Analiza danych jakościowych. Warszawa: Wydawnictwo Naukowe PWN.

Glinka, B., Hensel, P. (2012). Pułapki i dylematy w badaniach jakościowych. W: D. Jemielniak (red.), Badania jakościowe. Podejścia i teorie. Warszawa: Wydawnictwo Naukowe PWN.

Kopciewicz, L. (2009). Fenomenografia jako metoda badań kultury w jej wymiarze codziennym. Pedagogika Kultury, 5, 105-116.

Krajewski, M. (2008). Przedmiot, który uczłowiecza. Kultura Współczesna, 3 (57), 43-54.

Krajewski, M. (2013). Sa w życiu rzeczy... Szkice z socjologii przedmiotów. Warszawa: Fundacja Nowej Kultury Bęc Zmiana.

Kvale, S. (2004). InterViews. Wprowadzenie do jakościowego wywiadu badawczego. Przeł. S. Zabielski. Białystok: Trans Humana.

Kvale, S. (2010). Prowadzenie wywiadów. Przeł. A. Dziuban. Warszawa: Wydawnictwo Naukowe PWN.

Miksza, M. (2010). Zrozumieć Montessori. Czyli Maria Montessori o wychowaniu dziecka. Kraków: Oficyna Wydawnicza „Impuls”.

Montessori, M. (2005). Domy dziecięce. Warszawa: Wydawnictwo Akademickie „Żak”.

Okoń, Cz. (2016). Wprowadzenie do dydaktyki ogólnej. Warszawa: Wydawnictwo Akademickie „Żak”. 
Piłsudski, J. (1924). Pierwsze nagranie Józefa Piłsudskiego: stoję przed dziwaczna trąbą (Archiwum Polskiego Radia), Kanał Polskie Radio, YouTube. Pozyskano z: https://www.youtube. com/watch?v=94XkizoQoek [data dostępu: 17.09.2019].

Półturzycki, J. (1999). Dydaktyka dla nauczycieli. Toruń: Wydawnictwo Adam Marszałek.

Rybus, A. (2015). Czy rzecz może być sprawcą? Perspektywa humanistyki i nauk społecznych. W: A. Rybus, M.W. Kornobis (red.), Ludzie w świecie przedmiotów. Przedmioty w świecie ludzi. Warszawa: Wydawnictwa Uniwersytetu Warszawskiego.

Sierocki, R. (2008). Kultura rzeczy. W: J. Kowalewski, W. Piasek, M. Śliwa (red.), Rzeczy i ludzie. Humanistyka wobec materialności. Olsztyn: Instytut Filozofii Uniwersytetu Warmińsko-Mazurskiego.

Ustawa z 14 grudnia 2016 r. Prawo oświatowe (Dz.U. 2017, poz. 59).

Waszczyńska, K. (2015). Przedmowa. W: A. Rybus, M.W. Kornobis (red.), Ludzie w świecie przedmiotów. Przedmioty wświecie ludzi. Warszawa: Wydawnictwa Uniwersytetu Warszawskiego.

Wielki Słownik Języka Polskiego (2018). Warszawa: Wydawnictwo Naukowe PWN, r-t, Stanisław Dubisz, s. 265.

\section{SUMMARY}

The Specificity and Role of Things in Everyday Work of Teachers of Practical Vocational Training

The purpose of the article is to present the specificity and role of things in everyday work of teachers of practical vocational training. The analysis of qualitative research results allowed to notice the great importance of things in the daily work of vocational school teachers. A teacher deprived of access to things would experience great difficulties in providing students with practical skills: they are an indispensable link in the teaching-learning process.Things can endanger the lives and health of both teachers and students.In addition, they are often an additional element for which the teacher bears responsibility in class. Properly equipping a school with things and tools determines its prestige, and things constitute an element of competition between schools. Some can even perform a disciplinary role.

KEYWORDS: things, vocational school, everyday life, vocational teacher 